\title{
The influence of availability of free school milk on the height of children in England and Scotland
}

\author{
JUDITH COOK, LESLIE M. IRWIG, SUSAN CHINN, \\ DOUGLAS G. ALTMAN, AND CHARLES du V. FLOREY \\ From the Department of Community Medicine, St. Thomas's Hospital Medical School, London
}

SUMMARY The effect is investigated of availability of free school milk on height gain in one year of six- and seven-year-old primary schoolchildren in England and Scotland, using data collected annually from 1972 to 1976 . The height gain of children for whom milk was available for the whole year of observation was compared with that of children who had no milk. Out of 16 sex-country-year-specific analyses for children from manual social classes only, 13 showed no significant evidence of greater height gain in children who had milk. Comparison of children from Social Classes IV and V (semi-skilled and unskilled) showed no greater increase in height for those who had milk, nor was there a difference in height gain between manual social class children according to the number of glasses of milk they drank a day at home or at school. We concluded that, given the standard of living at the time of the survey, the drinking of free school milk did not increase the growth rate of six- and seven-year-old children.

From 1964 until the autumn of 1968 , one third of a pint of milk was available free of charge each school day to all children attending school. The government discontinued the supply of free school milk to secondary schoolchildren in the autumn of 1968. Since 1971 , as a result of further changes in school nutrition policy, free school milk has been available routinely to primary schoolchildren only until the end of the summer term after their seventh birthday (Great Britain, 1971). The policy was changed again in 1978 so that all children up to the age of 11 would have free milk available.
In 1971 there was no contemporary work on the influence of food supplementation on children's growth. There was, however, some evidence dating from before the second world war that supplementation of the diet of children with milk resulted in faster growth rates (Corry-Mann, 1926; National Institute for Research on Dairying, 1939). Because of concern about the possibly detrimental effects of the restriction of free school milk and other changes in food policy, the Department of Health and Social Security sponsored studies, through the Committee on Medical Aspects of Food Policy

\section{CHANGE OF STYLE}

Next year this journal and many others will change to the numerical system of styling references in accordance with the Vancouver agreement on uniform requirements for manuscripts submitted to biomedical journals. Authors are -therefore asked to note that papers for the first issue of 1980 and thereafter must be submitted in the revised style.

Under the new system, a paper or book or report cited in the text is referred to there by a superscript arabic number. In the reference list, papers, books, reports, etc., are numbered in the order in which they are first cited in the text, instead of in alphabetical order of authors' names. The titles of journals should be abbreviated as stated in the Index Medicus. Some examples of the new forms of references are given below.

JOURNAL PAPER

${ }^{1}$ Doll R, Peto R. Mortality in relation to smoking: 20 years' observations on male British doctors. $\mathrm{Br} \mathrm{Med} \mathrm{J} \mathrm{1976;} \mathrm{2:}$ $1525-1536$.

BOOK

${ }^{2}$ Rose GA, Blackburn H. Cardiovascular Survey Methods. Geneva: WHO, 1968.

CHAPTER IN BOOK

${ }^{\text {s}}$ Fletcher CM, Oldham PD. Bibliography on observer error and variation. In: Witts LJ, ed. Medical Surveys and Clinical Trials. London: Oxford University Press, 1961: 43-49.

For a detailed explanation of the new system, copies of the Vancouver agreement (50p, post free) can be obtained from the Publishing Manager, British Medical Journal, BMA House, Tavistock Square, London WC1H 9JR. 
(COMA), to monitor the health and growth of vulnerable groups in the population. One of these studies, the National Study of Health and Growth, was set up to assess the feasibility of a system of surveillance of schoolchildren. Information on the availability of free school milk was included in the data collected.

At the time when the study was set up, COMA believed that the chances of obtaining a positive result from a milk-feeding trial were small, and the difficulty of interpretation enormous (Department of Health and Social Security, 1973). Data from the National Study of Health and Growth (Altman and Cook, 1973) have therefore been used to test the hypothesis that the availability of free school milk is associated with faster growth rates.

\section{Method}

The study, a mixed longitudinal survey of primary schoolchildren in a sample of 28 areas in England and Scotland, started in 1972. The sample of areas was weighted to include more poorer areas (Altman and Cook, 1973).

The children's heights were measured on a specially designed stadiometer (Holtain) at each school by a school nurse and assistant, supervised by a trained field worker. The method, as described by Tanner et al., (1966), was recommended by Weiner and Lourie (1969) for the International Biological Programme. Height was recorded to the last complete $0.5 \mathrm{~cm}$ on the scale; subsequently $0.25 \mathrm{~cm}$ was added to each mean height to be reported in this paper. Each year a subsample of children was measured by both nurse and trained field worker; for $95 \%$ of these children the difference in measurement was $0.5 \mathrm{~cm}$ or less (Irwig, 1976). Measurements were taken approximately one year apart. The main analysis in this paper was carried out on the data from 1972 and 1973 surveys, and the figures refer to these data unless otherwise stated.

Information about the milk available to each child was obtained by asking the parent or guardian each year in a self-administered questionnaire if free school milk was currently available to the child. The parent or guardian was also asked whether the child drank the free milk if it was available, and how many glasses of milk the child usually drank at home each day.

Two groups of children were selected for comparison of height gained between the 1972 and 1973 surveys. One group contained children whose parents or guardians stated that free milk was available at the time of both surveys. The other contained children whose parents or guardians stated that it was not available at either time; these groups will be referred to as the YES-YES and the NO-NO groups. The height gain of children for whom free school milk was available in 1972 but not in 1973 (the YES-NO group) was also compared with the other two groups. The numbers of children in each group are shown in Table 1 by year of birth. In order to perform the analysis, it was necessary that the ages of the children in the YES-YES and NO-NO groups should be reasonably comparable, while maintaining adequate numbers in the two groups. Only the cohort born in 1965 provided sufficient numbers; this cohort was therefore used for the analysis of the data collected in 1972 and 1973.

Table 1 Numbers of children by year of birth and availability of free milk as defined by parental reports, 1972-1973

\begin{tabular}{|c|c|c|c|c|c|}
\hline & $\begin{array}{l}\text { Year of } \\
\text { birth }\end{array}$ & $N O-N O$ & $Y E S-N O$ & $Y E S-Y E S$ & TOTAL \\
\hline $\begin{array}{l}\text { ENGLAND } \\
\rightarrow\{\end{array}$ & $\left\{\begin{array}{l}1961 \\
1962 \\
1963 \\
1964 \\
1965 \\
1966 \\
1967\end{array}\right.$ & $\begin{array}{r}219 \\
736 \\
910 \\
768 \\
197 \\
8 \\
3\end{array}$ & $\begin{aligned} & 2(2) \\
& 10(9) \\
& 10(9) \\
& 234(207) \\
& 508(462) \\
& 177(164) \\
& 13(11)\end{aligned}$ & $\begin{aligned} & 5(5) \\
& 15(13) \\
& 21(18) \\
& 20(17) \\
& 237(199) \\
& 720(636) \\
& 619(569)\end{aligned}$ & $\begin{array}{r}226 \\
761 \\
941 \\
1022 \\
942 \\
905 \\
635\end{array}$ \\
\hline $\begin{array}{r}\rightarrow \\
\text { SCOTLAND }\end{array}$ & $\begin{array}{l}1961 \\
1962 \\
1963 \\
1964 \\
1965 \\
1966 \\
1967\end{array}$ & $\begin{array}{r}31 \\
162 \\
188 \\
168 \\
97 \\
3 \\
1\end{array}$ & $\begin{aligned} 2 & (2) \\
11 & (10) \\
14 & (11) \\
22 & (21) \\
77 & (73) \\
89 & (86) \\
8 & (8)\end{aligned}$ & $\begin{aligned} & 15(14) \\
& 44(42) \\
& 32(30) \\
& 29(28) \\
& 57(51) \\
& 174(160) \\
& 214(195)\end{aligned}$ & $\begin{array}{r}48 \\
217 \\
234 \\
219 \\
231 \\
266 \\
233\end{array}$ \\
\hline
\end{tabular}

In brackets are the numbers of children reported by parents or guardians to drink free milk in 1972 in the YES-NO group and in both 1972 and 1973 in the YES-YES group.

$\rightarrow$ Cohort used for main analysis.

If free school milk had been provided for each child exactly as laid down by government policy, the children in the YES-YES group would have been less than eight years old at the end of the summer term after they were seen in 1973 and the NO-NO group would have been at least seven years old at the end of the 1971 summer term, so the ages of the two groups could not have overlapped. However, information supplied by the schools indicated that the 1971 policy change was not applied uniformly: some schools were supplying milk according to each child's age as government policy dictated, some according to the age of the majority of children in a class, and a few were supplying it to all children in the primary school. Because of these variations, we found that the children in the two groups in the 1965 cohort had very similar age distributions. Among the English children in the cohort, who were surveyed mainly in the summer term, there was a difference in mean age of about eight months between the two groups. 
However, because of the variations in policy, the age ranges overlapped (6.4 to $7 \cdot 7$ years for the NO-NO group and 6.3 to 7.4 years for the YES-YES group).

Among the Scottish children, all of whom were surveyed in the autumn term, the difference in mean age was less than two months; the range for both groups was $6 \cdot 7$ to $7 \cdot 7$ years.

In the 1972 survey there were 1561 children born in 1965 . When children not followed up in 1973 were omitted, together with those for whom parental milk reports were not obtained in both years, 1210 children remained.

The parental report on free milk availability was NO in 1972 and YES in 1973 for 37 children; these were excluded, because it is likely that at least one of the reports was incorrect. This left 1173 children, 942 English and 231 Scottish (Table 1). In order to analyse height gain, a further 21 children who moved schools between 1972 and 1973 were excluded, as were seven non-Caucasians and 18 children for whom no measurement was obtained at one or both surveys. A total of 1127 children remained, 467 boys and 435 girls in England, 114 boys and 111 girls in Scotland.

Covariance analysis of height gain was used to compare groups defined by milk availability, allowing for age differences of the children in 1972 and slight deviations from one complete year in the time between measurements (time gap). We have found that height velocity at a given age increases with attained height (unpublished results). Any differences in height between the groups in 1972 could not have been due to differences in the availability of free school milk before 1972, because free school milk would have been available to all children in the cohort. It was therefore appropriate to consider height gain additionally adjusted for differences in attained height in 1972. In fact an equivalent analysis was made by comparing 1973 attained height adjusted for differences in 1972 attained height, age, and time gap. Because of the possibility that only disadvantaged children may benefit from free school milk, data for children from manual social classes (IIIB, IV, and V) were analysed separately. Information on social class was obtained from the 1972 questionnaires; the numbers of children in the analyses including this variable were reduced substantially because of the relatively poor response to the questions on occupation (75\% overall).

\section{Results}

The numbers of children born in 1965 are given in Table 1 according to the availability of school milk as reported by the parent or guardian (indicated by arrows). Of the children who had milk in both 1972 and 1973, 84\% in England and 89\% in Scotland were reported to have drunk it.

The results obtained for height gain by milk availability as stated by the parent or guardian are shown in Table 2 . Mean values of height gain have

Table 2 Mean height gain 1972 to 1973 and mean adjusted 1973 height by country, sex, and milk availability groups

\begin{tabular}{|c|c|c|c|c|c|c|c|c|}
\hline & $\begin{array}{l}\text { Milk } \\
\text { availability }\end{array}$ & $\begin{array}{l}\text { No. of } \\
\text { children }\end{array}$ & $\begin{array}{l}\text { Mean age } \\
1972 \\
\text { (years) }\end{array}$ & $\begin{array}{l}\text { Mean height } \\
1972 \\
(\mathrm{~cm})\end{array}$ & $\begin{array}{l}\text { Mean height } \\
\text { gain 1972-73 } \\
\text { adjusted to time } \\
\text { gap } 1 \text { year, and } \\
\text { age } 7 \text { in } 1972 \\
\text { (cm) }\end{array}$ & $\begin{array}{l}\text { Value of ' } t \text { ' } \\
\text { for difference } \\
\text { between } N O-N O \\
\text { and YES-YES } \\
\text { groups }\end{array}$ & $\begin{array}{l}\text { Mean height } \\
1973 \text { adjusted to } \\
\text { time gap } 1 \text { year, } \\
\text { age } 7 \text { and } \\
\text { height } 120 \mathrm{~cm} \text { in } \\
1972(\mathrm{~cm})\end{array}$ & $\begin{array}{l}\text { Value of ' } t \text { ' } \\
\text { for difference } \\
\text { between NO-NO } \\
\text { and YES-YES } \\
\text { groups }\end{array}$ \\
\hline \multicolumn{9}{|c|}{ ENGLAND } \\
\hline Boys & $\begin{array}{l}\text { NO-NO } \\
\text { YES-NO } \\
\text { YES-YES } \\
\text { Total }\end{array}$ & $\begin{array}{r}98 \\
253 \\
116 \\
467\end{array}$ & $\begin{array}{l}7 \cdot 33 \\
7 \cdot 04 \\
6 \cdot 65\end{array}$ & $\begin{array}{l}123 \cdot 25 \\
121 \cdot 20 \\
118 \cdot 81\end{array}$ & $\begin{array}{l}5 \cdot 77 \\
5 \cdot 92 \\
6 \cdot 07\end{array}$ & 1.70 & $\begin{array}{l}125 \cdot 98 \\
126 \cdot 13 \\
126 \cdot 27\end{array}$ & $1 \cdot 75$ \\
\hline Girls & $\begin{array}{l}\text { NO-NO } \\
\text { YES-NO } \\
\text { YES-YES } \\
\text { Total }\end{array}$ & $\begin{array}{r}90 \\
234 \\
111 \\
435\end{array}$ & $\begin{array}{l}7 \cdot 37 \\
7 \cdot 06 \\
6 \cdot 67\end{array}$ & $\begin{array}{l}121 \cdot 86 \\
120 \cdot 19 \\
118 \cdot 18\end{array}$ & $\begin{array}{l}5 \cdot 92 \\
5 \cdot 87 \\
5 \cdot 88\end{array}$ & -0.22 & $\begin{array}{l}126 \cdot 21 \\
126 \cdot 13 \\
126 \cdot 11\end{array}$ & -0.73 \\
\hline $\begin{array}{c}\text { SCOTL } \\
\text { Boys }\end{array}$ & $\begin{array}{l}\text { NO-NO } \\
\text { YES-NO } \\
\text { YES-YES } \\
\text { Total }\end{array}$ & $\begin{array}{r}45 \\
38 \\
31 \\
114\end{array}$ & $\begin{array}{l}7 \cdot 39 \\
7 \cdot 16 \\
7 \cdot 25\end{array}$ & $\begin{array}{l}123 \cdot 42 \\
121 \cdot 99 \\
120 \cdot 10\end{array}$ & $\begin{array}{l}5 \cdot 87 \\
5 \cdot 80 \\
5 \cdot 60\end{array}$ & $-1 \cdot 31$ & $\begin{array}{l}126.09 \\
126 \cdot 02 \\
125 \cdot 97\end{array}$ & -0.63 \\
\hline Girls & $\begin{array}{l}\text { NO-NO } \\
\text { YES-NO } \\
\text { YES-YES } \\
\text { Total }\end{array}$ & $\begin{array}{r}48 \\
38 \\
25 \\
111\end{array}$ & $\begin{array}{l}7 \cdot 44 \\
7 \cdot 20 \\
7 \cdot 34\end{array}$ & $\begin{array}{l}122 \cdot 03 \\
120 \cdot 84 \\
120 \cdot 93\end{array}$ & $\begin{array}{l}5 \cdot 54 \\
5 \cdot 54 \\
6 \cdot 05\end{array}$ & $2 \cdot 20 *$ & $\begin{array}{l}125 \cdot 82 \\
125 \cdot 82 \\
126 \cdot 35\end{array}$ & $2 \cdot 41 *$ \\
\hline
\end{tabular}

Key: $\quad$ NO-NO Free milk available neither year

$+\mathbf{P}<0.05$

YES-NO Free milk available 1972, not 1973

YES-YES Free milk available both years 
been adjusted to the age of seven years and time gap one year, using the regression coefficients for the appropriate sex and country, pooled over the three milk availability groups. There was a significantly greater mean height gain for Scottish girls in the YES-YES group than in the NO-NO group (difference $0.51 \mathrm{~cm}, \mathrm{P}<0.05$ ).

The results of the covariance analysis of height in 1973 are also shown in Table 2 . The mean height in 1973 has been adjusted to a height in 1972 of $120 \mathrm{~cm}$ as well as to age of seven years and time gap of one year. Scottish children, although previously shown to be shorter than English children at the same age (Rona and Altman, 1977), were taller on average at the time of survey than English children because they were all measured in the autumn term. The results were similar to those for height gain; the difference in adjusted mean height of Scottish girls in the two groups was $0.53 \mathrm{~cm}(\mathrm{P}<0.05)$. The corresponding difference in English boys was $0.29 \mathrm{~cm}(\mathrm{P}<0.1)$. In this case the mean adjusted height of the YES-NO group lay between the mean adjusted heights of the other two groups; in Scottish girls it was equal to that of the NO-NO group.

For English girls and Scottish boys the YES-YES group had the lowest adjusted 1973 height, and the NO-NO group the greatest, but the difference in each case was not significant.

The analysis was repeated for children in the manual social classes on the assumption that they would be nutritionally at a disadvantage compared with children in the non-manual social classes and might therefore be more likely to show an effect of milk (Table 3). In the manual social classes, for
English boys and Scottish girls the difference between the YES-YES and NO-NO groups was slightly larger than that estimated for all children (Table 2) but no significant difference was found for English girls or Scottish boys in the manual social classes.

The analyses were repeated for later cohorts of children measured in subsequent years-namely, children born in 1966 measured in 1973 and 1974; children born in 1967 measured in 1974 and 1975; and children born in 1968 measured in 1975 and 1976. Numbers and ages were comparable to those in the main analysis. In analyses of all children and of manual social class children alone (Table 4) the only significant difference in mean height gain between the NO-NO and the YES-YES groups was in English boys born in 1966. Results for adjusted attained height were similar.

Because it was possible that the effect of milk would be discernible only in the most disadvantaged, we analysed children from Social Classes IV and V only. There were too few in any one year, so these children in the four cohorts were combined. There was no significant increase in height gain for the YES-YES compared with the NO-NO groups in any of the four sex-country groups $(P>0 \cdot 2)$; in Scottish girls the NO-NO group gained nearly one centimetre more than the YES-YES group $(P<0.05)$.

Table 5 shows the consumption of milk at home by manual social class children according to the availability of milk as reported by their parents orôㅇ guardians. Only $2 \%$ of children drank no milk at? home. In England and Scotland the YES-YES groups of boys drank very slightly less at home on average

Table 3 Mean height gain 1972 to 1973 for children in manual social classes by country, sex, and milk availability groups

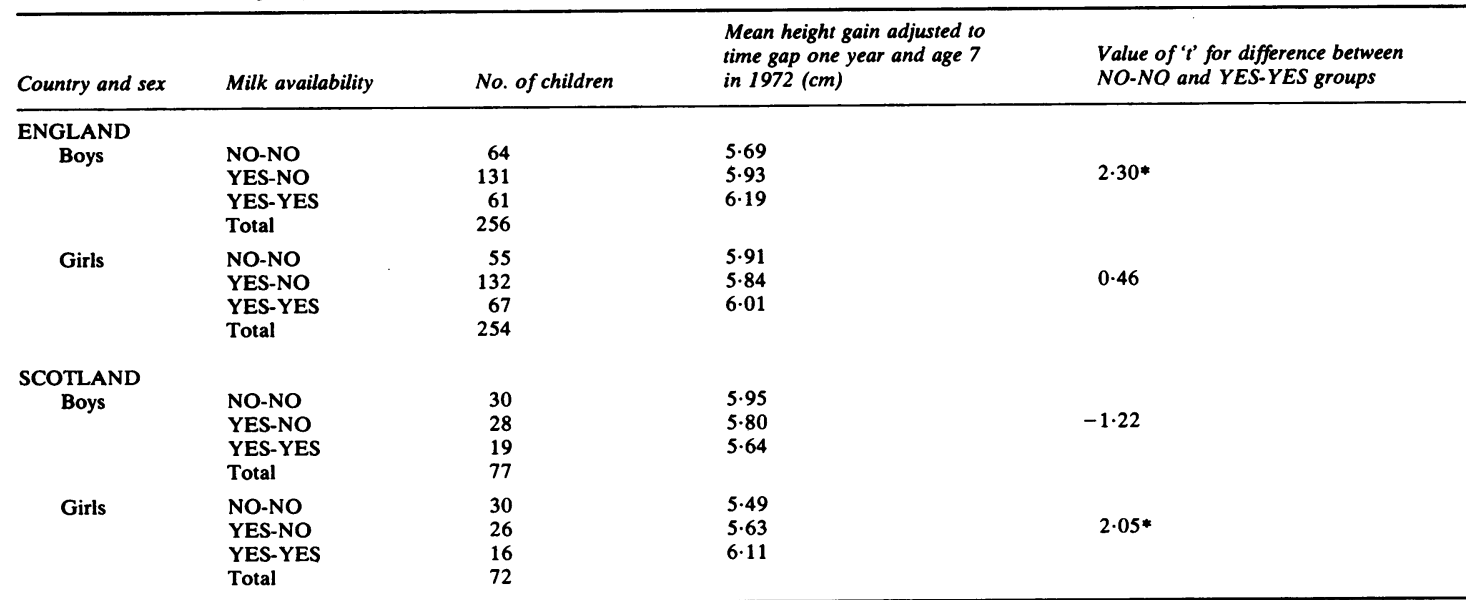


Table 4 Mean height gain of three cohorts of children from manual social classes by country, sex, and milk availability groups

\begin{tabular}{|c|c|c|c|c|c|c|c|}
\hline $\begin{array}{l}\text { Cohort } \\
\text { Year }\end{array}$ & & $\begin{array}{l}1966 \\
1973-1974\end{array}$ & & $\begin{array}{l}1967 \\
1974-1975\end{array}$ & & $\begin{array}{l}1968 \\
1975-1976\end{array}$ & \\
\hline Milk availability & & $\begin{array}{l}\text { Mean height gain } \dagger \\
(\mathrm{cm})\end{array}$ & $' t '$ & $\begin{array}{l}\text { Mean height gain } \dagger \\
(\mathrm{cm})\end{array}$ & $' t$ ' & $\begin{array}{l}\text { Mean height gain } \dagger \\
(\mathrm{cm})\end{array}$ & $' t '$ \\
\hline $\begin{array}{c}\text { ENGLAND } \\
\text { Boys }\end{array}$ & $\begin{array}{l}\text { NO-NO } \\
\text { YES-YES }\end{array}$ & $\begin{array}{l}5 \cdot 39 \\
6 \cdot 06\end{array}$ & $3 \cdot 32 * * *$ & $\begin{array}{l}5 \cdot 60 \\
5 \cdot 88\end{array}$ & $1 \cdot 22$ & $\begin{array}{l}5 \cdot 83 \\
5 \cdot 66\end{array}$ & -0.77 \\
\hline Girls & $\begin{array}{l}\text { NO-NO } \\
\text { YES-YES }\end{array}$ & $\begin{array}{l}5 \cdot 63 \\
5 \cdot 85\end{array}$ & $1 \cdot 07$ & $\begin{array}{l}5 \cdot 80 \\
5 \cdot 70\end{array}$ & -0.48 & $\begin{array}{l}5 \cdot 53 \\
5 \cdot 74\end{array}$ & 0.93 \\
\hline $\begin{array}{c}\text { SCOTLAND } \\
\text { Boys }\end{array}$ & $\begin{array}{l}\text { NO-NO } \\
\text { YES-YES }\end{array}$ & $\begin{array}{l}5 \cdot 56 \\
5 \cdot 38\end{array}$ & -0.74 & $\begin{array}{l}5 \cdot 26 \\
5 \cdot 40\end{array}$ & 0.53 & $\begin{array}{l}5 \cdot 57 \\
5 \cdot 91\end{array}$ & $1 \cdot 11$ \\
\hline Girls & $\begin{array}{l}\text { NO-NO } \\
\text { YES-YES }\end{array}$ & $\begin{array}{l}5 \cdot 55 \\
5 \cdot 18\end{array}$ & $-1 \cdot 20$ & $\begin{array}{l}6 \cdot 03 \\
5 \cdot 77\end{array}$ & -0.77 & $\begin{array}{l}5 \cdot 79 \\
5 \cdot 55\end{array}$ & -0.62 \\
\hline
\end{tabular}

$* * * P<0.001$

† Adjusted to time gap one year and age 7 at the first survey. The value of ' $t$ ' is for the difference between the YES-YES and the NO-NO groups.

Table 5 Consumption of milk at home by children in manual social classes by country, sex, and milk availability groups, 1972

\begin{tabular}{|c|c|c|c|c|c|c|c|}
\hline & & \multicolumn{5}{|c|}{ Number of glasses per day* } & \multirow{2}{*}{$\begin{array}{l}\text { Total no. } \\
\text { of children } \\
(100 \%)\end{array}$} \\
\hline & & 0 & 1 & 2 & 3 & $4+$ & \\
\hline & & \multicolumn{5}{|c|}{$\%$ in group } & \\
\hline \multicolumn{8}{|c|}{ ENGLAND } \\
\hline Boys & $\begin{array}{l}\text { NO-NO } \\
\text { YES-NO } \\
\text { YES-YES }\end{array}$ & $\begin{array}{l}2 \\
2 \\
5\end{array}$ & $\begin{array}{l}14 \\
15 \\
18\end{array}$ & $\begin{array}{l}36 \\
30 \\
25\end{array}$ & $\begin{array}{l}27 \\
32 \\
30\end{array}$ & $\begin{array}{l}21 \\
21 \\
22\end{array}$ & $\begin{array}{r}81 \\
174 \\
73\end{array}$ \\
\hline Girls & $\begin{array}{l}\text { NO-NO } \\
\text { YES-NO } \\
\text { YES-YES }\end{array}$ & $\begin{array}{l}2 \\
2 \\
3\end{array}$ & $\begin{array}{l}22 \\
15 \\
19\end{array}$ & $\begin{array}{l}32 \\
35 \\
23\end{array}$ & $\begin{array}{l}31 \\
28 \\
30\end{array}$ & $\begin{array}{l}14 \\
20 \\
25\end{array}$ & $\begin{array}{r}65 \\
162 \\
77\end{array}$ \\
\hline \multicolumn{8}{|c|}{ SCOTLAND } \\
\hline Boys & $\begin{array}{l}\text { NO-NO } \\
\text { YES-NO } \\
\text { YES-YES }\end{array}$ & $\begin{array}{l}3 \\
0 \\
0\end{array}$ & $\begin{array}{r}8 \\
10 \\
14\end{array}$ & $\begin{array}{l}30 \\
31 \\
33\end{array}$ & $\begin{array}{l}27 \\
28 \\
19\end{array}$ & $\begin{array}{l}32 \\
31 \\
33\end{array}$ & $\begin{array}{l}37 \\
29 \\
21\end{array}$ \\
\hline Girls & $\begin{array}{l}\text { NO-NO } \\
\text { YES-NO } \\
\text { YES-YES }\end{array}$ & $\begin{array}{l}0 \\
3 \\
0\end{array}$ & $\begin{array}{r}17 \\
7 \\
17\end{array}$ & $\begin{array}{l}31 \\
37 \\
50\end{array}$ & $\begin{array}{l}17 \\
27 \\
28\end{array}$ & $\begin{array}{r}35 \\
27 \\
6\end{array}$ & $\begin{array}{l}35 \\
30 \\
18\end{array}$ \\
\hline
\end{tabular}

* A glass is approximately one-third of a pint.

than the NO-NO groups. The girls in the two countries differed: in England the YES-YES group drank a fifth of a glass more per day on average than the NO-NO group, but in Scotland the YES-YES group drank nearly half a glass less per day on average.

To see whether height gain was related to the quantity of milk drunk, a regression of height on the total number of glasses of milk drunk at school plus home was carried out, allowing for differences in age and time gap, for manual social class children in the 1965 cohort. There was no effect of the average milk consumption on height gain in any sex-country group $(\mathrm{P}>0 \cdot 3)$.

\section{Discussion}

The National Study of Health and Growth was initiated at a time of changes in policy on free school milk, but its main aim was the surveillance of growth in primary schoolchildren. It was not designed specifically to assess the effects of the changes in milk policy, but data were available which could give some indication of whether addition or withdrawal of free milk was in any way related to growth. Within these constraints, we have shown that no consistent increases in growth over one-year periods for the years 1972-1976 occurred in children for whom milk was available.

We set out to test the hypothesis that the policy of providing free milk would lead to higher growth rates. We based this on the assumption that more children with free milk available would drink it at school than those who had to pay for it. This assumption was probably correct because reported uptake of free school milk in the 1972 survey was 90\% in England and Scotland, whereas children rarely reported that they bought milk or brought it from home. Nineteen children in one English area and in Scotland, one in one area, and six in another reported thus. However, substantial quantities of milk were drunk at home by all groups of children. The results given in Table 5 support the view that the few significant differences found between the YES-YES and NO-NO groups were chance findings. In the 1965 cohort of English girls, whose milk consumption could be expected to produce the largest difference in growth, there was no statistically significant difference, whereas in Scottish girls for whom a significant difference was found, the free school milk would have raised the average total milk consumption of the YES-YES group by only half a 
glass (one-sixth of a pint) more than that of the NO-NO group.

In English boys the difference in growth might be ascribed to the difference in total milk consumption but the finding of a similar effect would have been expected in Scottish boys, who were no less deprived than those in the English sample.

Because the data for the 1965 cohort were not consistent with any alternative hypothesis, and because in subsequent cohorts only one significant difference in growth could be found, we believe that the availability of school milk has no real effect on group well-being where drinking milk at home is almost universal. It is possible, though, that the most deprived children benefit from milk. Our study was not designed specifically to test this, although we have tried to assess the effects of availability of milk in deprived groups defined by social class. But some indication may be had from two other studies. One of these, carried out in orphans (Corry-Mann, 1926), suggested that the addition of one pint of milk a day to a basic diet led to substantially higher growth rates and increased well-being. More recently a randomised controlled trial has been reported in which milk was provided to selected primary schools in South Wales (Baker et al., 1978). The analysis was of 520 children aged seven to eight years old with three or more siblings in their families; of these, $98 \%$ were in Social Classes IIIA-V, 23\% came from families where the father was unemployed, and $8 \%$ were from single parent families. After 21 months of observations, no difference in height gain was found between boys provided with milk and their controls $(9.2 \mathrm{~cm}$ compared with $9.1 \mathrm{~cm})$, but the girls provided with milk grew somewhat more than their controls $(9.72 \mathrm{~cm}$ compared with $9.27 \mathrm{~cm} \mathrm{p} \bumpeq 0.06)$. These preliminary results pose similar problems to our own, because there was some evidence that the availability of milk might have had an effect, but it was difficult to substantiate even in children who were more disadvantaged than average.

The results of our study and the one in South Wales do not give unequivocal answers about the value of free school milk in Britain today, but the weight of the evidence suggests that any effect, if it exists, must be very small.

We thank all the people involved in the National Study of Health and Growth: doctors, nurses and teachers in the study areas; the administrator and field workers of our department; Professor W. W. Holland (director); Mrs. A. Childs; and Mr. R. Morris. The study is supported by a grant from the Department of Health and Social Security.

Reprints from Dr. Charles du V. Florey, Department of Community Medicine, St. Thomas's Hospital Medical School, London SE1 7EH.

\section{References}

Altman, D. G., and Cook, J. (1973). A nutritional surveillance study. Proceedings of the Royal Society of Medicine. 66, 646-647.

Baker, I. A., Elwood, P. C., Hughes, J., Jones, M., and Sweetnam, P. M. (1978). School milk and growth in primary schoolchildren. Lancet, 2, 575.

Corry-Mann, H. C. (1926). Diets for boys during the school age. Medical Research Council Special Report Series No. 105. HMSO: London.

Department of Health and Social Security. (1973). First Report by the Sub-Committee on Nutritional Surveillance. Reports on Health and Social Subjects No. 6. HMSO: London.

Great Britain, Parliament (1971). Statutory Instruments, 1, 368. HMSO: London.

Irwig, L. M. (1976). Surveillance in developed countries with particular reference to child growth. International Journal of Epidemiology, 5, 57-61.

National Institute for Research on Dairying (Reading) and the Rowett Research Institute. (1939). Milk and Nutrition, part 4. Pynder and Son: Reading.

Rona, R. J., and Altman, D. G. (1977). Standards of attained height, weight and triceps skinfold. Annals of Human Biology, 4, 501-523.

Tanner, J. M., Whitehouse, R. H., and Takaishi, M. (1966). Standards from birth to maturity for height, weight, height velocity, weight velocity: British children. Archives of Disease in Childhood, 41, 613-635.

Weiner, J. S., and Lourie, J. A. (1969). Human Biology: A Guide to Field Methods. International Biological Programme Handbook No. 9. Blackwell Scientific Publications: Oxford. 